\title{
OS DESAFIOS DA FORMAÇÃO DO LEITOR CONTEMPORÂNEO E A LITERATURA DIGITAL
}

\section{CONTEMPORARY READER TRAINING CHALLENGES AND DIGITAL LITERATURE}

\author{
José Batista de Souza* \\ Ana Flora Schlindwein**
}

\begin{abstract}
Resumo: O presente trabalho é fruto de uma prática de leitura de hipercontos realizada com uma turma de alunos do $9^{\circ}$ ano de uma escola pública baiana, sendo parte de um Projeto de Qualificação de Mestrado em Letras da Universidade Federal de Sergipe, cujo objetivo é ampliar as possibilidades de leitura do texto literário por parte dos discentes, no suporte digital e no impresso, e contribuir com a formação desses alunos. Apesar de parciais, os resultados apontam a literatura digital, neste caso específico o hiperconto, como um caminho positivo para trabalhar a formação do leitor contemporâneo, principalmente por sua natureza mais interativa e pela hipermodalidade.
\end{abstract}

Palavras-Chave: Formação do Leitor. Hiperconto. Hipertexto. Literatura. Literatura Digital.

\begin{abstract}
The present paper is the result of a practice of reading of hyper short stories carried out with a group of students of the 9th grade of a public school in Bahia, being part of a Master's Degree in Literature Project of the Federal University of Sergipe, which has as an objective to expand the possibilities of reading of the literary text by the students, in digital and print format, and contribute to the formation of those students. Although partial, the results show that the digital literature, specifically hyper short story, as a positive path to work with the formation of the contemporary reader, mainly because its interactive natures and its hypermodality.
\end{abstract}

Keywords: Reading skills. Hyper shot story. Hypertext. Literature. Digital Literature.

\section{Introdução}

A leitura é uma das ferramentas mais importantes para a formação do sujeito/cidadão tendo em vista que, através dela, ele terá a possibilidade de aprender os caminhos necessários para viver em sociedade, conhecendo o seu contexto social e o de outros, a pluralidade cultural, religiosa, ideológica, dentre outras, que perpassa o nosso planeta. Através da leitura, o indivíduo conhece o mundo à sua volta e tem a oportunidade de se reconhecer nele como um partícipe ativo da estrutura social, com direitos e deveres, podendo se tornar um ser cada vez mais humano, já que, dentre as possibilidades oferecidas pela leitura, está o desenvolvimento de um pensamento crítico.

\footnotetext{
* Mestrando do Profletras da Universidade Federal de Sergipe - Campus de Itabaiana. E-mail: jbdesouza@bol.com.br.

** Doutora em Linguística Aplicada pela Unicamp e professora do Departamento de Letras Libras da Universidade Federal de Sergipe - Campus São Cristóvão e do Programa de Pós-Graduação em Letras Profletras - Campus Itabaiana. E-mail: profianafloraufs@gmail.com.
} 
A leitura sempre foi um assunto de interesse nacional e internacional - por razões diversas e, às vezes, divergentes. É comum nos depararmos com índices de desempenho em leitura que tendem a mostrar como o Brasil se encontra em relação às demais nações e também em relação às suas próprias metas. Considerando apenas os dados numéricos, a posição do país em relação à leitura tem deixado muito a desejar, o que tem preocupado sobremaneira nossos dirigentes governamentais, nossas escolas, pais de alunos e a sociedade como um todo. Por exemplo, de acordo com uma pesquisa sobre leitura e cultura em âmbito internacional, realizada pela Market Research World $^{1}$ em 2016, os países que estão no topo quando o assunto é leitura e cultura são: $1^{\circ}$, Índia (mantendo essa posição desde 2005); $2^{\circ}$ Tailândia; $3^{\circ}$, China; $4^{\circ}$, Filipinas; e $5^{\circ}$, Egito, coincidentemente (ou não), todos asiáticos. Nessa pesquisa, que envolveu 30 países, o Brasil ocupou apenas a $27^{a}$ posição, ficando atrás de países como é a Argentina e a Venezuela, este último, o país mais leitor da América Latina.

Conforme a $4^{\text {a }}$ Edição da Pesquisa ${ }^{2}$ 'Retratos da Leitura no Brasil', realizada também em 2016, pelo Instituto Pró-Livro, 30\% da população brasileira nunca comprou um livro. A pesquisa revelou ainda que os brasileiros leem em média 2,43 livros ao ano. Em relação aos gostos dos leitores, a pesquisa apontou também que cerca de $25 \%$ dos leitores leem por gosto, enquanto cerca de $7 \%$ leem por exigência escolar. Não cabe no escopo deste trabalho questionar esses índices - como qual o conceito de "leitura" adotado nessas pesquisas, qual a metodologia escolhida e qual o intuito da coleta desses dados - fato é que devemos promover uma leitura diversificada e significativa para os nossos discentes.

Ao considerarmos os últimos dados do $\mathrm{IDEB}^{3}$ - Índice de Desenvolvimento da Educação Básica, realizado em 2017, constatou-se que, no tocante aos resultados do Ensino Fundamental séries finais, esse apresentou, apesar de ter crescido um pouco, resultados inferiores ao Ensino Fundamental séries iniciais e, como sabemos, dentre alguns aspectos, o IDEB avalia a proficiência dos alunos em leitura, o que aponta para a escola empreender ações na tentativa de melhorar o nível dos alunos em leitura e, consequentemente, contribuir com o cálculo do IDEB ${ }^{4}$.

No tocante aos resultados apresentados na última avaliação do PISA $^{5}-$ Programa Internacional de Avaliação de Estudantes, realizado em 2015, em relação ao índice de dificuldade em leitura por estudantes brasileiros, a avaliação demonstrou que precisamos melhorar bastante, principalmente porque muitos alunos não estão conseguindo ultrapassar a superfície textual.

Não há dúvida de que a escola vem investindo mais nas habilidades de leitura. Entretanto, ainda estamos muito presos a um trabalho de leitura cujo foco é a superfície do texto que se oferece aos olhos do

\footnotetext{
1 Disponível em: https://bvl.org.br/quais-sao-os-paises-mais-leitores-do-mundo/. Acesso em 30 de novembro de 2018 e em http://livrarianobel.com.br/index.php/quais-sao-os-paises-mais-leitores-domundo/. Acesso em 30 de novembro de 2018.

2 Disponível em: http://prolivro.org.br/home/images/2016/Pesquisa_Retratos_da_Leitura_no_Brasil_2015.pdf. Acesso em 30 de novembro de 2018.

${ }^{\overline{3}}$ O Índice de Desenvolvimento da Educação Básica (IDEB) é um indicador criado pelo governo federal para medir a qualidade do ensino nas escolas públicas. Para um maior esclarecimento acerca do acessar o site oficial: http://portal.inep.gov.br/ideb

${ }^{4}$ Vale consultar o site http://inep.gov.br/consulta-ideb para ter acesso a todos os dados de 2017, último IDEB realizado.

5 Para uma compreensão a respeito do PISA sugerimos uma consulta atenta ao http://portal.inep.gov.br/pisa-no-brasil.
} 
leitor, em busca de informações específicas, localizadas ou, em outro extremo, da opinião do aluno, seu posicionamento sobre o que diz o texto (BRASIL, 2016, p. 111).

Assim, precisamos incentivar a leitura, em outras palavras, descobrir alternativas para estimular os alunos no tocante à leitura, alternativas essas que valorizem os seus gostos e, ao mesmo tempo, estimule-os para a leitura do texto literário, uma vez que a literatura, como sinaliza Cândido (1995), é uma questão de direitos humanos, e os alunos precisam ser orientados a usufruir desse direito, orientação que deve partir tanto da família quanto da escola. É a partir do texto literário que o aluno pode descobrir realidades outras que ele não conhecia, ou se enxergar no próprio texto. Ou seja, ele pode mergulhar nas camadas mais profundas do texto e descobrir coisas inimagináveis, mas, para isso, a escola precisa investir em diferentes habilidades de leituras pelos alunos para que eles ultrapassem a leitura superficial.

Nos últimos tempos, tem-se percebido uma grande mudança no perfil do leitor, mudança essa caracterizada pela popularização das Novas Tecnologias da Informação e Comunicação - NTIC ${ }^{6}$. O leitor de hoje usa o seu smartphone ou tablet ${ }^{7}$ como suporte de diferentes tipos de textos, algo muito comum principalmente entre os leitores mais jovens.

Por uma série de diversos fatores, o leitor de hoje normalmente não consegue mais permanecer horas numa biblioteca lendo um livro, no silêncio esperado nesse ambiente. O leitor atual é mais dinâmico, que lê de formas múltiplas, em diferentes suportes, em movimento e no mundo virtual, tanto é que tem sido chamado por Santaella $(2004 ; 2013)$ de leitor imersivo/virtual, devido ao fato de grande parte de suas leituras serem realizadas na tela.

Assim, embora nossos índices de leitura dos livros impressos estejam sendo evidenciados do ponto de vista negativo, como apontaram as pesquisas anteriormente citadas, tem-se percebido um grande aumento da leitura realizada na tela (computador, tablet, notebook e celular $)^{8}$, sendo observável como os jovens se comunicam intensamente através de seus smatphones, lendo e escrevendo, gravando áudios e vídeos, produzindo conteúdo.

$\mathrm{O}$ ato de ler está presente, no entanto, talvez o tipo de leitura que eles têm realizado possa não ser visto com bons olhos por muitos, já que geralmente eles leem por diversão, por entretenimento - uma leitura "descompromissada", não tão valorizada quanto a leitura de um texto literário como apontam Santos, Gross e Spalding (2017).

Apesar da leitura na tela apresentar características positivas, temos percebido que existem alguns desafios na formação do leitor contemporâneo, dentre eles: compreender os diferentes tipos de produção que existem no mundo digital; a confiabilidade do material lido; seu espaço dentro do universo de textos; sua função social e etc. É papel da escola dar bases norteadoras aos alunos quanto à forma mais adequada de se ler na tela.

A literatura digital, uma das vertentes da literatura geral e em grande ascensão nos últimos tempos, tem sido bem aceita entre os leitores mais jovens, e, apesar dos docentes encontrarem muitos desafios para formar o leitor nesse contexto de

\footnotetext{
${ }^{6}$ Toda vez que aparecer a expressão Novas Tecnologias da Informação e Comunicação, estaremos nos referindo ao computador e seus derivados conectados à internet.

7 MONTEIRO et al. A popularização dos smatphones e tablets. Disponível no endereço: <http://www.etechortolandia.com.br/novo/files/ptcc_smartphones.pdf>

${ }^{8}$ Disponível em: http://www.ceale.fae.ufmg.br/pages/view/a-leitura-no-mundo-digital.html
} 
diversidade e de suportes, a literatura na tela tem se apresentado como um caminho fecundo para a formação do leitor contemporâneo, colocando-se não como uma alternativa melhor, mas como uma possibilidade de ampliação do hábito de leitura por parte do aluno e de formação do leitor literário, pois, como sinaliza Abreu (2006), quando se trata de gosto literário, não existe gosto melhor ou pior, o que tira a literatura digital da posição de concorrente da literatura impressa tradicional e a coloca como uma aliada na formação do leitor contemporâneo.

Assim, visando oportunizar aos alunos do $9^{\circ}$ ano da escola pesquisada uma nova possibilidade de leitura do texto literário, já que eles apresentavam dificuldades em leitura e resistência pela leitura do texto impresso, optou-se por uma prática de leitura de hipercontos, uma produção que tem despertado interesse devido a toda a dinamicidade que ela possui e ao seu caráter híbrido e multissemiótico. Trata-se de uma escola pública municipal da cidade de Coronel João Sá, estado da Bahia. Quanto à turma de $9^{\circ}$ ano envolvida nessa pesquisa, trata-se de uma turma do turno vespertino, com alunos todos oriundos da zona urbana.

Por ser uma produção que agrega várias semioses (texto escrito, imagens estáticas ou em movimento, cores, som e links), o hiperconto consegue captar a atenção do leitor e fazer com que ele permaneça na tela por um tempo bem maior do que ele provavelmente passaria diante de um texto impresso, que normalmente é composto apenas por um texto escrito, às vezes com a presença de imagens estáticas. Dessa forma, com a leitura de hipercontos, que não deixa de ser um texto literário, já que é uma nova forma no ambiente digital do conto tradicional, é bem provável que o aluno se interesse por ler cada vez mais, não apenas na tela, mas também no suporte impresso, conforme aponta Spalding (2012).

Nessa perspectiva, este trabalho tem amparo em Spalding (2012) no tocante à proposta de interpretação do hiperconto como sendo um novo gênero presente no ambiente digital e à sua concepção de literatura digital; Hayles (2009), ao abordar a literatura eletrônica; Chartier (2002), ao discorrer sobre a tecnologia do computador e a do livro impresso; Gomes (2011), ao discutir a respeito do hipertexto; Santaella (2004; 2013), ao tratar do novo perfil do leitor atual e da comunicação ubíqua, dentre outros.

\section{Literatura Digital}

Uma das características do chamado "mundo globalizado" é o deslocamento virtual das pessoas, ou seja, a possibilidade de elas estarem em diversos lugares ao mesmo tempo, mesmo estando fisicamente num único local. As pessoas hoje leem bastante na tela do computador ou do smartphone - às vezes mais de um texto simultaneamente -, podendo se comunicar ao mesmo tempo com pessoas que estão em outros lugares. Isso só é possível graças à ubiquidade das coisas, possibilitada pela internet, isto é, à possibilidade de o sujeito estar em diversos lugares ao mesmo tempo sem, no entanto, se deslocar (SANTAELLA, 2013). Assim, com o barateamento de tablets e smartphones (COUTINHO, 2014) o aluno tem a possibilidade de ler em diferentes lugares, textos de todos os tipos, cabendo ao professor direcioná-lo para que ele utilize seu celular para ler também o texto literário, ou seja, contos, crônicas, poemas, fábulas, etc.

A literatura digital, como a própria expressão aponta, nasce a partir do digital (seja o computador, notebook, tablet ou smatphone) e tem tido um crescimento e uma 
aceitação bastante significativos entre os leitores, principalmente os mais jovens adeptos das NTIC. Tais tecnologias têm modificado de diversas formas o mundo globalizado no qual vivemos, a exemplo dos nossos hábitos de leitura, como aponta Spalding (2012). Abaixo podemos visualizar um site de literatura digital - um dos mais visitados do Brasil.

Figura 1: Captura de tela do site mais conhecido do Brasil sobre literatura digital

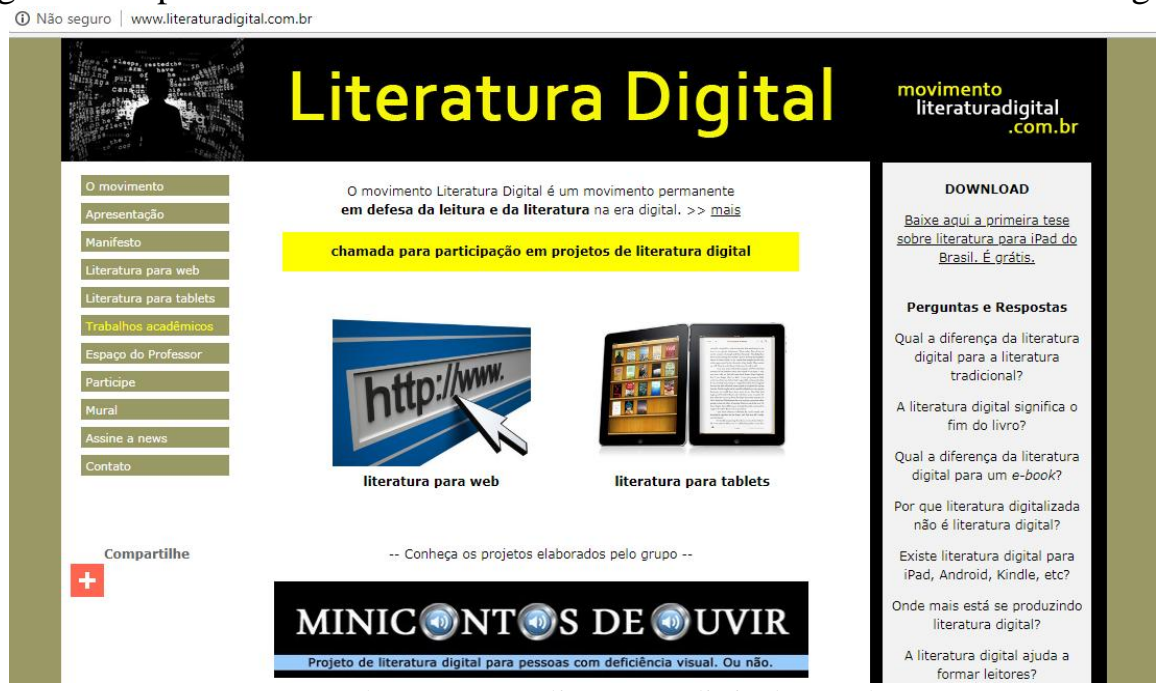

Fonte: http://www.literaturadigital.com.br/

Segundo Hayles (2009, p. 20), a "literatura eletrônica, geralmente considerada excludente da literatura impressa que tenha sido digitalizada, é, por contraste, nascida no meio digital, um objeto digital de primeira geração criado pelo uso de um computador e (geralmente) lido em uma tela de computador". Ou seja, trata-se de obras literárias pensadas para a tela, tanto a produção quanto a leitura, a exemplo da cyberpoesia e do miniconto de ouvir. Essa vertente da literatura geral é marcada pela animação, pelo hipertexto e pela interatividade entre autor o leitor, o que a torna bastante interessante, principalmente para os adolescentes, que geralmente gostam de textos mais interativos.

Mesmo sendo uma grande defensora da literatura eletrônica/digital, Hayles (2009) sinaliza que ela não tem uma boa aceitação entre muitos defensores da literatura tradicional impressa, alguns dos quais, devido à "liberdade" que a literatura digital permite ao leitor, acabam taxando-a apenas de entretenimento. Ou seja, como se o clicar num link ou numa caixa de som, o leitor se distraísse e não conseguisse fazer a fruição do texto literário, ou ainda, que as outras semioses do texto na tela desfocassem o leitor do principal - o texto. No entanto, para os defensores da literatura digital, todos os recursos multimodais presentes no texto ajudam na significação do texto e na ampliação do letramento para os multiletramentos, uma vez que o leitor, ao conjugar diferentes semioses acaba, inclusive, ampliando o sentido do texto, como apontam Rojo e Moura (2012).

Essa "liberdade", na verdade, é uma oportunidade que o autor de literatura digital dá ao leitor, a possibilidade de fazer escolhas durante a leitura do texto por meio, por exemplo, de links e decidir sobre seu enredo, algo que não ocorre na literatura tradicional, na qual o "controle" do texto é "exclusivo" do autor, concebido como o centro da obra. 
Muito embora vários autores literários no contexto de suas obras já tivessem destacado a importância do papel do leitor, como Cervantes, em Dom Quixote (1605), Machado de Assis, em Memórias Póstumas de Bras Cubas (1881), Unamuno, em Niebla (1914), Pirandello, em Seis Personagens à procura de um autor (1921), entre outros, considera-se o ensaio de Barthes, A morte do autor, de 1968, como o inaugurador de uma postura pós-estruturalista de crítica ao papel centralizador do autor que atinge autores do porte de Foucault, Lacan, Ricoeur e Umberto Eco (SANTOS, 2007, p. 03).

Na perspectiva de Santos, Gross e Spalding (2017, p. 124), "a literatura digital transpõe as bordas da literatura impressa, pois rompe com o caráter estático do texto literário ao apresentar produções dinâmicas, atrativas e interativas". Isso pode ser bastante perceptível a partir da exploração de produções digitais como Minicontos de Ouvir, Hipercontos e Cyberpoesias, que podem chamar a atenção do leitor por conta da multissemiose neles presente:

[...]. Os textos escritos para serem lidos no computador - os chamados "textos digitais" - têm características bastante particulares e diferentes daquelas dos textos escritos tradicionais. Não basta publicar um texto na internet para que ele se torne um texto digital. Não é incomum, portanto, que muitos textos da internet precisem ser impressos para que se efetue uma leitura mais precisa - são textos construídos no padrão tradicional de escrita e meramente transpostos para a tela (BRAGA e RICARTE, 2005, p. 41).

Vale frisar que, diferentemente do que pensam alguns autores da literatura tradicional impressa, a literatura digital contribui bastante para a formação do leitor. Apesar do aspecto lúdico desse tipo de literatura, apresentando som, imagens estáticas ou em movimento e links, o leitor tem todo um trabalho de construção/interpretação do texto, pois precisa extrair dele sentidos possíveis, com a diferença de que a leitura pode ser mais agradável/envolvente ao se clicar em um ícone de som que acompanha o texto, por exemplo, conjugando o texto e a música. Além disso, a característica mais marcante da literatura digital é a possibilidade que o leitor tem de fazer escolhas e colaborar na construção da tessitura textual, podendo escolher o percurso do texto, desafiando inclusive a questão da autoria, como aponta Cani (2017). Nessa linha de raciocínio, é pertinente ressaltar que:

A literatura digital [...] sofre com o preconceito da crítica literária. Apesar disso ela é uma realidade e está cada vez mais presente na formação de novos leitores e escritores. Essa resistência ao novo é gerada pelo medo eterno de que uma nova tecnologia possa matar algo que seja considerado precioso [...]. O estranhamento gerado pelas publicações literárias na internet tem fundamento quando se toma a leitura como um processo construído pelo hábito e experiência. Levase tempo para formar um hábito social e por essa razão torna-se difícil desmistificá-lo. Entretanto, a literatura virtual é uma realidade e tem formado costumes, sendo assim merecedora de atenção e pesquisa (DUARTE, 2011, p. 02-03). 
Essa sempre foi uma das grandes preocupações de alguns autores, a exemplo de Chartier (2002), a de que a tecnologia do computador pudesse substituir o livro. No entanto "o livro continua sendo objeto de encanto e paixão de muitas pessoas, e ele pode sim, ser considerado como algo insubstituível [...]" (SANTOS; GROSS; SPALDING, 2017, p. 120). Nessa ótica, faz-se mister enfatizar que a literatura digital não surgiu para competir com a literatura impressa, nem tem feito isso, afinal, falar em literatura digital não é falar de um novo tipo de literatura, mas de uma ampliação da literatura geral.

Como se tem observado, atualmente, alunos adolescentes, na faixa etária entre 12 e 13 anos têm lido cada vez mais na tela, inclusive obras literárias. É muito comum, enquanto professor, ouvir nos intervalos das aulas ou nas próprias aulas os alunos comentarem sobre terem ou estado lendo determinada obra através do celular, bem como de ouvir colegas professores comentarem casos semelhantes de seus alunos ${ }^{9}$. Mas, para reforçar esse dado e dar impessoalidade à pesquisa, pode-se mencionar uma experiência a esse respeito realizada com alunos das séries finais do ensino fundamental de uma escola do campo no interior do Rio Grande do Sul - uma pesquisa realizada por uma professora, e que versava sobre a leitura digital no contexto escolar. Dentre as atividades aplicadas pela docente para conhecer os hábitos de leitura dos discentes e seus gostos pessoais no tocante à leitura, do universo de 20 alunos que aceitaram participar da pesquisa, ao responderem a questão que indagava sobre o campo da leitura digital, apenas 03 alunos demonstraram nunca ter lido um livro em versão digital. Dos 17 que assinalaram já ter lido obras digitais, apenas 03 sinalizaram não ter gostado da experiência, o que aponta um caminho a ser explorado pelos professores de ensino fundamental dos anos finais (SCHOLL; LIMA, 2008). Por isso é oportuno para o docente apresentar aos discentes a literatura digital, para que eles, ao terem contato com essa produção, possam gostar do texto literário na tela e passem a ler também o livro impresso, algo que eles talvez não tenham o hábito ou que leiam com pouca frequência. Assim:

A nova vertente de literatura que aqui expomos, a Literatura Digital,
não vem como um recurso aleatório para preencher o tempo, ou
simplesmente, justificar a necessidade de se usar a tecnologia em sala
de aula. É uma forma legítima e autoral de arte. É fruto da idealização
de escritores que têm um compromisso com a arte da palavra e em
formar novos leitores. São novas formas de leituras para leitores de
novos tempos (SANTOS; GROSS; SPALDING, 2017, p. 128).

Concordando com os autores cabe comentar que fazer literatura na tela, apesar das críticas que surgem, não é nada fácil, uma vez que o autor precisa ter, além do traquejo com a escrita tradicional, um bom domínio acerca das Novas Tecnologias da Informação e Comunicação. Mais do que isso, precisa pensar em um projeto criativo, que agregue o texto escrito a diferentes semioses, tornando-o atrativo aos olhos do leitor sem, no entanto, deixar a desejar no aspecto literário. Ou seja, não é porque está na tela que não é literário. $\mathrm{O}$ texto na tela tem condição de causar no leitor a mesma emoção que ele sente quando lê no suporte impresso. A musicalidade, a expressividade, o brincar com as palavras, a criatividade no uso da linguagem também são perceptíveis no

\footnotetext{
${ }^{9}$ Nesse momento, saio da posição de pesquisador e me coloco na de professor que, no dia a dia, enquanto professor de Língua Portuguesa, ouço de alguns alunos sobre suas experiências de lerem livros digitais através do celular.
} 
suporte digital, razão pela qual é uma boa alternativa para o professor aproveitar o gosto dos alunos pelas mídias digitais para estimulá-los para a leitura do texto literário. Observemos a captura de tela da página organizada por Ana Cláudia Gruszinsky e Sérgio Capparelli - duas figuras bastante notórias no contexto da literatura digital do Brasil. Essa página mostra-se bastante interativa, possibilitando ao leitor mergulhar na brincadeira e criar sua própria poesia digital a partir dos clicks sobre os tópicos expostos na tela.

Figura 2 - Captura de tela do site ciberpoesia

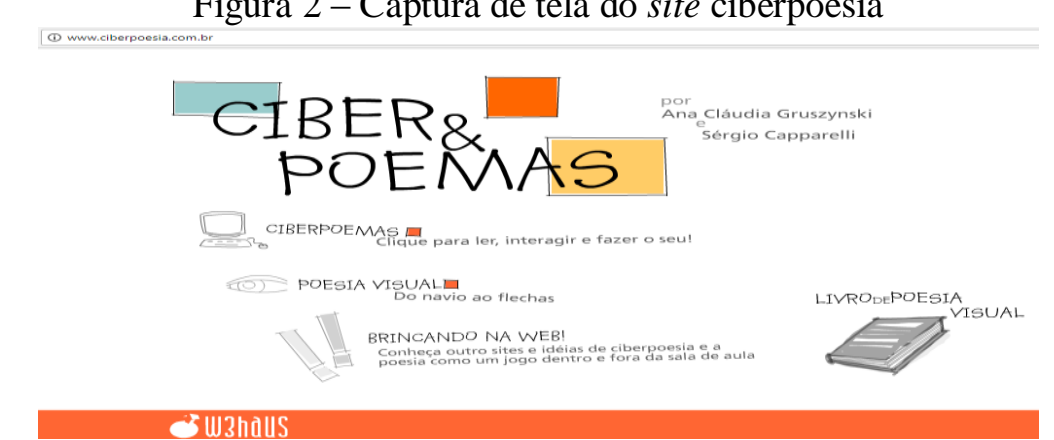

Fonte: http://www.ciberpoesia.com.br/. Acesso em 18 de outubro de 2018

Portanto defendemos nesta pesquisa uma literatura na tela diferente da impressa, com mais dinamicidade, com mais possibilidade de participação do leitor, mas sem perder sua característica mais importante: a fruição literária. O leitor precisa captar através da tela a emoção e todos os sentidos possíveis que o texto apresenta, além daqueles que ele próprio pode construir a partir dos implícitos, afinal, um dos principais pontos que defendemos é um leitor mais ativo e participativo que, juntamente com o autor, constrói o sentido do texto e divide, inclusive, a autoria.

\section{O Gênero Hiperconto}

O hiperconto é um dos gêneros explorados pela literatura na tela e geralmente não é conhecido do grande público, afinal, seu surgimento é recente, datado de 2009, quando foi criado por Marcelo Spalding, um nome expressivo da literatura digital brasileira. No entanto, entre aqueles que tiveram contato, a aceitação é bastante significativa, como será explicitado mais adiante.

Ao analisarmos o termo, notamos logo de cara a sua relação com o conto tradicional e, de fato, há uma relação intrínseca entre esses dois gêneros, tendo em vista que o hiperconto é uma nova concepção de conto, criado especificamente para ser lido na tela: ele geralmente é hipermodal, o que o torna bastante diferente do conto tradicional, apesar de manter suas principais características: narratividade, intensidade, tensão, ocultamento e autoria, como destaca Spalding (2012, p. 153). A ideia de hipermodalidade surge da análise de Lemke (2002) da fusão dos conceitos de multimodalidade e de hipertextualidade, fusão essa que também é observada por Araújo e Soares (2009, p. 04), que defendem que a hipermodalidade "é uma maneira de se 
nomear as novas interações entre os significados das palavras, imagens e sons na hipermídia".

Embora hipermodal, o hiperconto apresenta elementos constitutivos do conto tradicional, como ser curto, com poucos personagens, com uma única história desenvolvida e com um único clímax. No entanto, não se finda nessas características, uma vez que agrega a elas mais algumas, a exemplo de imagens em movimento, muitas cores, sons e links, sendo esse último o item mais importante, pois possibilita ao leitor fazer escolhas para construir o texto. Ou seja, a partir dos links deixados pelo autor (que podem ocorrer em qualquer parte do texto), o leitor vai clicando e escolhendo de que forma a história deve ser tecida, algo que o encanta, pois quem está lendo se sente importante na construção da tessitura textual, diferentemente do que ocorre no conto impresso, cujo desenrolar da história não é aberto e o seu fim já fora decidido previamente. Nesse contexto:

\begin{abstract}
O hiperconto seria uma versão do conto para a Era Digital (...). O texto, naturalmente, ainda deve ser o cerne do hiperconto, preservando seu caráter literário. Mas um bom hiperconto será capaz de aproveitar as ferramentas das novas tecnologias para potencializar a história que conta da mesma forma que os livros infanto-juvenis, por exemplo, têm se utilizado da ilustração. Imagens, em movimento ou não, áudios, hiperlinks, interatividade e quebra da linearidade são apenas algumas das possibilidades do hiperconto. Claro que um bom hiperconto não precisa utilizar todos esses recursos ao mesmo tempo (...). Mas também não podemos deixar de perceber que um conto de Borges simplesmente digitado e publicado na internet não passará a ser um hiperconto ou um exemplo de literatura digital apenas por estar na internet, e sim continuará a ser um belo conto de Borges (SPALDING, 2012, p. 153).
\end{abstract}

Com base no exposto por Spalding (2012), na citação anterior, percebe-se claramente as diferenças entre o conto e o hiperconto, sendo a mais marcante que o hiperconto tem seu início produzido pelo autor, mas, geralmente no meio, ele deposita links para que o leitor decida que rumo quer dar à história, ou seja, como ele quer que ela continue. Há, nesse caso, diferentes construções para uma única história, possibilitadas pelo artifício do uso de links, o que exige do autor bastante criatividade. Além do mais, o autor pode também deixar links no clímax da história, sugerindo dois ou três caminhos como opção de finalização do texto, como uma espécie de Linha Direta $^{10}$, em que o público decidia sobre o fim da história e dos criminosos.

Outra diferença notória entre conto e hiperconto é a questão da dinamicidade. Enquanto o primeiro é mais estático, fazendo uso, na maior parte do tempo, de apenas texto escrito, inserindo ora ou outra uma imagem para ilustrar a história, o segundo é bastante dinâmico e interativo, sendo não só multissemiótico, mas hipermodal. Uma

\footnotetext{
${ }^{10}$ Linha Direta foi um programa da Rede Globo, exibido nas noites de quinta-feira entre 1999 e 2007. O programa dedicava-se a apresentar crimes que aconteceram pelo Brasil e cujos autores estariam foragidos da Justiça. Inicialmente era apresentado por Marcelo Rezende [...]. Disponível: https://pt.wikipedia.org/wiki/Linha_Direta. Acesso em 18 de outubro de 2018.
} 
produção impressa jamais teria condições de reunir tantas semioses juntas num mesmo papel, algo totalmente possível numa tela de computador.

Diante disso, faz-se mister enfatizarmos a importância dos links para o gênero hiperconto. Eles são de fundamental importância, pois, sem eles, esse gênero não existiria, ou, se existisse, provavelmente não seria tão dinâmico como é. São os links que permitem ao leitor fazer escolhas, contribuir na construção do texto, ser mais ativo no processo de leitura. Quando está diante de um texto, o leitor tem um horizonte de expectativas, isto é, ele espera algo, tem expectativa de como o enredo do texto será construído (BORDINI; AGUIAR, 1989). No hiperconto, através dos links, o leitor ao clicar em um deles é movido pelo seu horizonte de expectativas, que pode se confirmar ou não. Ou seja, ao fazer uma escolha com base em seu horizonte de expectativas, o leitor pode ficar satisfeito, mas pode também perceber que, se tivesse feito outra escolha, talvez o texto tendesse para um caminho mais atrativo. De qualquer forma, ter diferentes possibilidades num mesmo texto é algo bastante significativo e cativante na literatura, o que faz da literatura digital um caminho fecundo para a formação do leitor, sendo uma escolha potencial para trabalhar com os alunos.

Cabe ressaltar a função retórica que os links possuem no texto, sendo fundamentais para a sua construção (GOMES, 2011). Por exemplo, mesmo as não escolhas do leitor, quando despreza determinados links em função de outros, apontam para uma construção de sentidos. Uma das maneiras de representar o que foi defendido aqui é o diagrama abaixo:

Figura 3: Diagrama representativo das funções retóricas dos links, em conformidade com a compreensão de Gomes (2011)

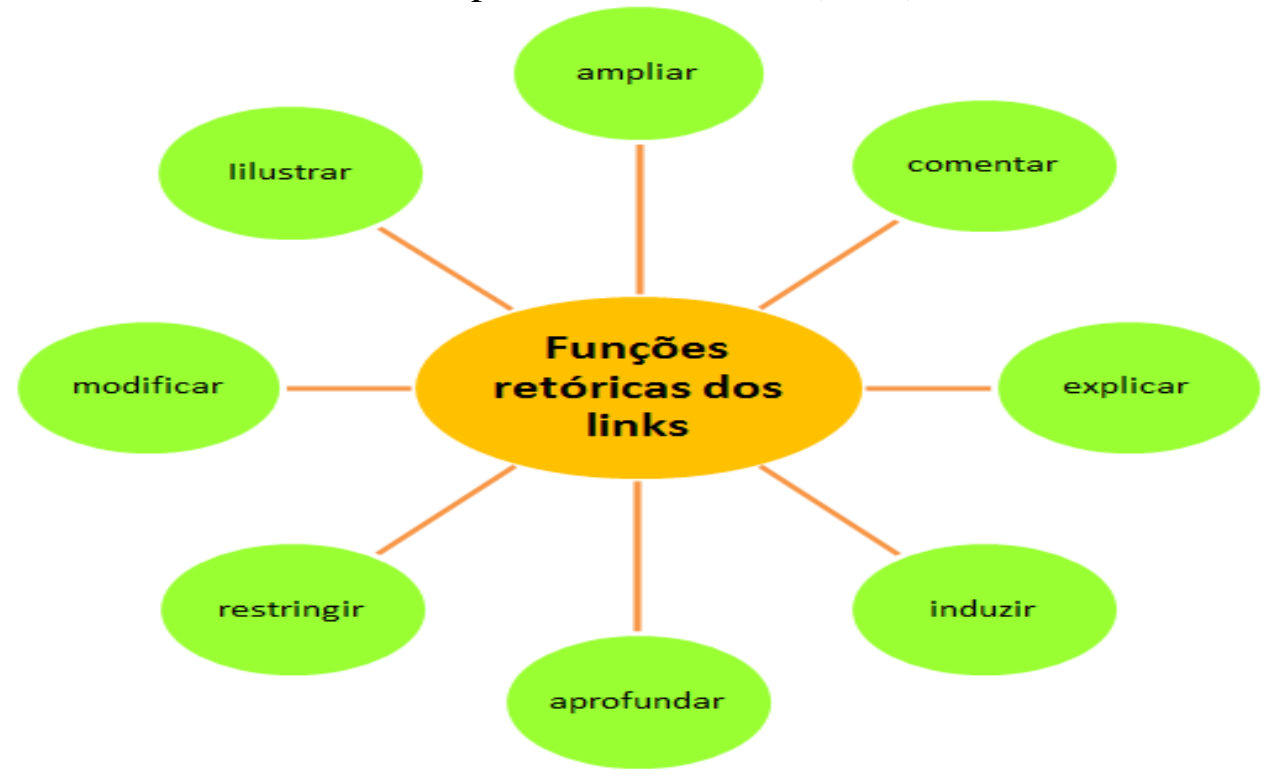

Fonte: http://flaviakarolinalima.wixsite.com/hipertextos/single-post/2015/10/13/Aula-9-

07102015. Acesso em 18 de outubro de 2018.

Através desse diagrama, podemos perceber as propostas de funções apresentadas por Gomes (2011), para os links e o que eles representam no texto. Assim, mais do que meros adereços, eles comunicam de várias formas diferentes, como é perceptível pelos verbos que explicam as possibilidades constitutivas dos links. Portanto, os links, 
fundamentais no hiperconto, são a marca registrada desse gênero hipertextual, devendo ser explorados ao máximo para a construção da tessitura textual e para a ampliação dos sentidos do texto.

\section{Prática de Leitura de Hipercontos}

Na turma de $9^{\circ}$ ano, foco da pesquisa ${ }^{11}$, ao começar a trabalhar com leitura, partindo do livro didático adotado pela escola, percebeu-se uma falta de prática de leitura desse material didático e de obras impressas, de modo geral. Os alunos geralmente deixavam o livro em casa e, quando era solicitado que eles lessem durante a aula, percebia-se uma resistência muito grande, como se eles não gostassem de ler, passando a impressão que o livro didático não fosse "atrativo" para eles. Além disso, em alguns momentos de leitura de textos impressos levados para a aula, notou-se algumas dificuldades em leitura, a exemplo de entonação, ritmo da leitura, tom de voz e dicção, variando essas dificuldades entre os alunos. Em conversas informais sobre suas leituras em casa, eles revelaram não ler livros, salvo raras exceções. Por outro lado, era comum vê-los ligados em seus celulares, lendo e escrevendo com bastante frequência e, apesar de muitos deles terem dito que não gostavam de ler, percebeu-se uma contradição da parte deles quanto a essa fala, pois ler era o que eles mais faziam em seus celulares.

Percebendo o interesse deles por tecnologia, foi necessário pensar numa proposta de estímulo à leitura que partisse exatamente de uma mídia digital, que poderia ser o computador ou o próprio celular. Nessa proposta, o foco seria a leitura de um texto literário na tela, já que tinha ficado claro o valor que os alunos davam ao celular. Por isso, aproveitando o fato de o hiperconto ser um gênero da literatura digital bastante cativante, principalmente aos olhos dos jovens, decidiu-se por apresentá-lo à turma, com o objetivo de que ela passasse a usar o celular também para outros tipos de leituras, como hipercontos e contos, ou seja, textos literários.

Assim, na sala de aula, durante duas aulas, através de um Datashow foram apresentados aos alunos dois hipercontos, algo que nenhum deles conhecia. $\mathrm{O}$ primeiro hiperconto mostrado na primeira aula foi Um tiro para a liberdade, contendo uma estrutura mais simples, porém permeado pela multimodalidade. Além do texto escrito ele possui imagens, cores, links e um videoclipe logo abaixo da imagem da garota.

Figura 4: Captura da primeira tela do hiperconto Um tiro para a liberdade

\footnotetext{
${ }^{11}$ A pesquisa foi realizada em uma turma de $9^{\circ}$ ano na qual o mestrando é professor.
} 


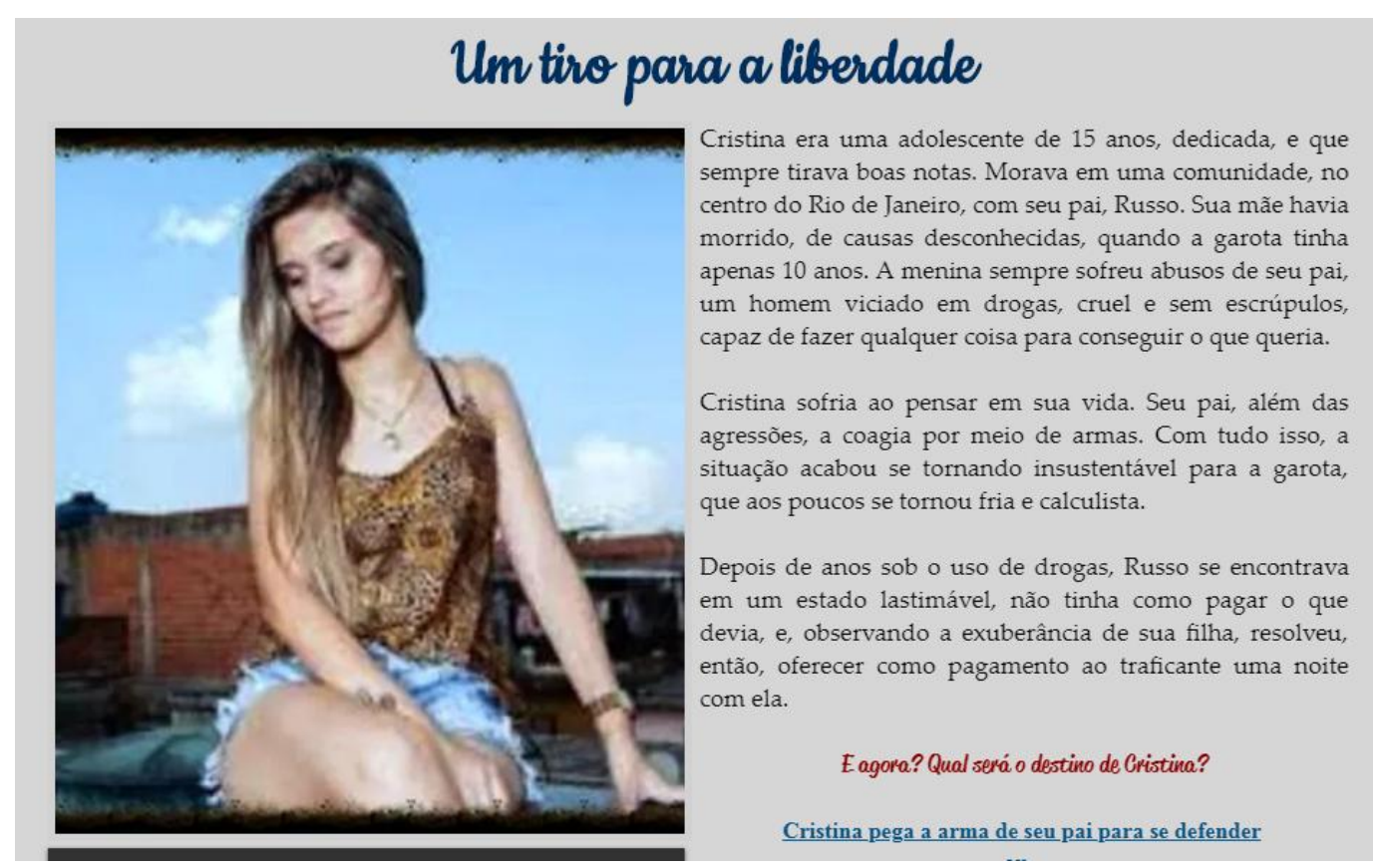

Fonte: http://garciaroberta38.wixsite.com/contosehipercontos/um-tiro-para-a-liberdade

Como se nota na captura de tela, que é apenas a primeira "página" do hiperconto, a história é iniciada e, no meio dela, o autor solicita a participação do leitor a partir do trecho destacado em vermelho. Logo abaixo, há dois links na cor azul para que o leitor clique em um deles e decida como ele quer que a história continue. Assim, iniciando a aula, foi feita a leitura do trecho inicial do hiperconto e, quando chegou o momento de escolher o caminho a ser seguido, foi necessário pedir que os alunos levantassem a mão caso quisessem escolher o primeiro link ou o segundo. Como são 13 alunos na turma, optou-se pela votação, tendo a maior parte dos alunos escolhido o segundo link. Nesse momento, percebeu-se o entusiasmo dos alunos por esse tipo de texto, tendo eles ficado encantados e bastante atentos. Para os discentes era uma novidade poder escolher o caminho de uma história, tendo em vista que geralmente o autor tem o controle de todo o enredo. Além disso, as telas eram repletas de imagens, o que chamava ainda mais a atenção deles.

Figura 4: Captura da segunda tela do hiperconto Um tiro para a liberdade 


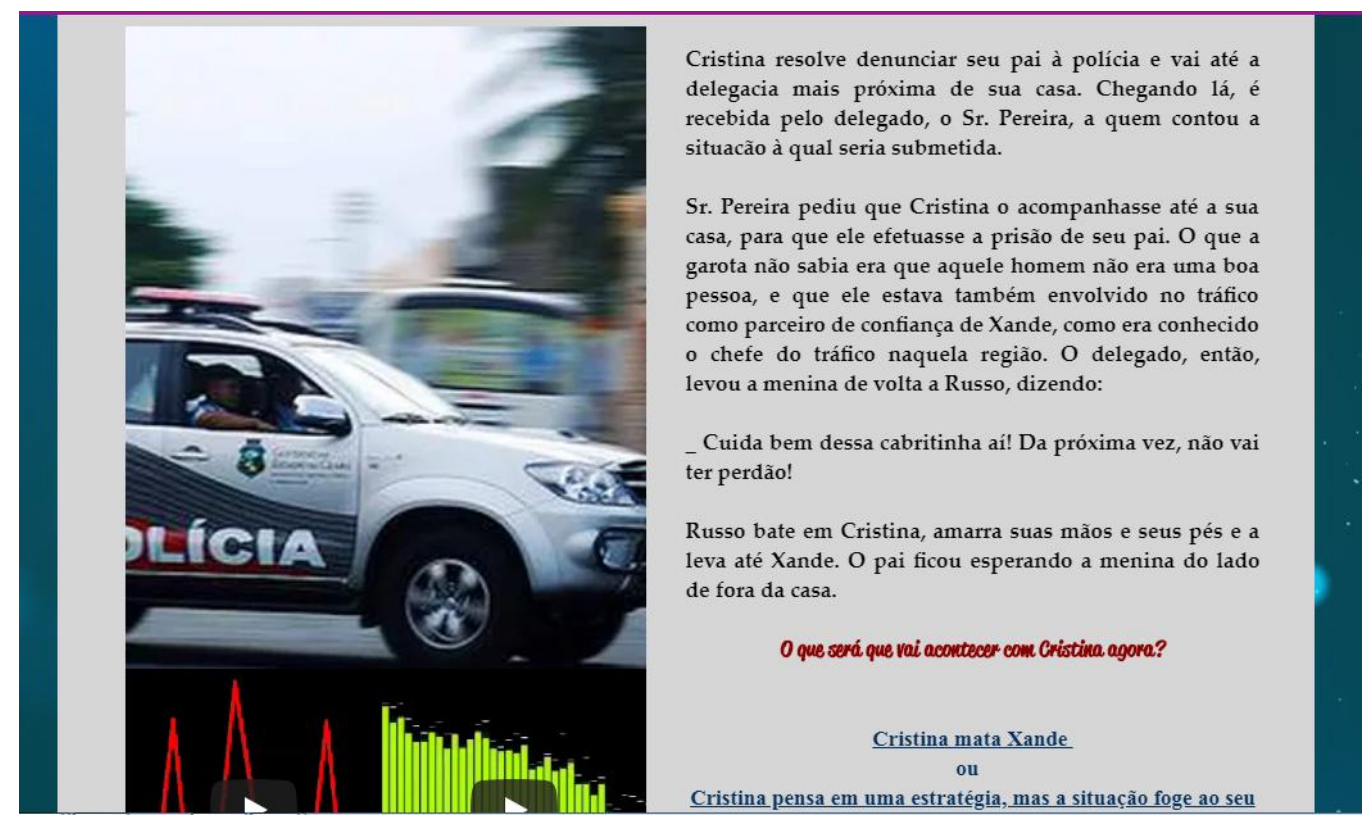

Fonte: http://garciaroberta38.wixsite.com/contosehipercontos/blank-oav0b

Assim que surgiu a segunda tela do hiperconto, foi dada a continuação à leitura da história, em voz alta (pelo professor) e, novamente, em uma parte estratégica da história, o autor dá mais duas possibilidades (dois links em azul) de o leitor participar. Mais uma vez foi solicitado que os alunos levantassem as mãos para escolher o link. Dessa vez, a maioria optou pelo primeiro link, que resultou na tela abaixo.

Figura 5: Captura da terceira tela do hiperconto Um tiro para a liberdade

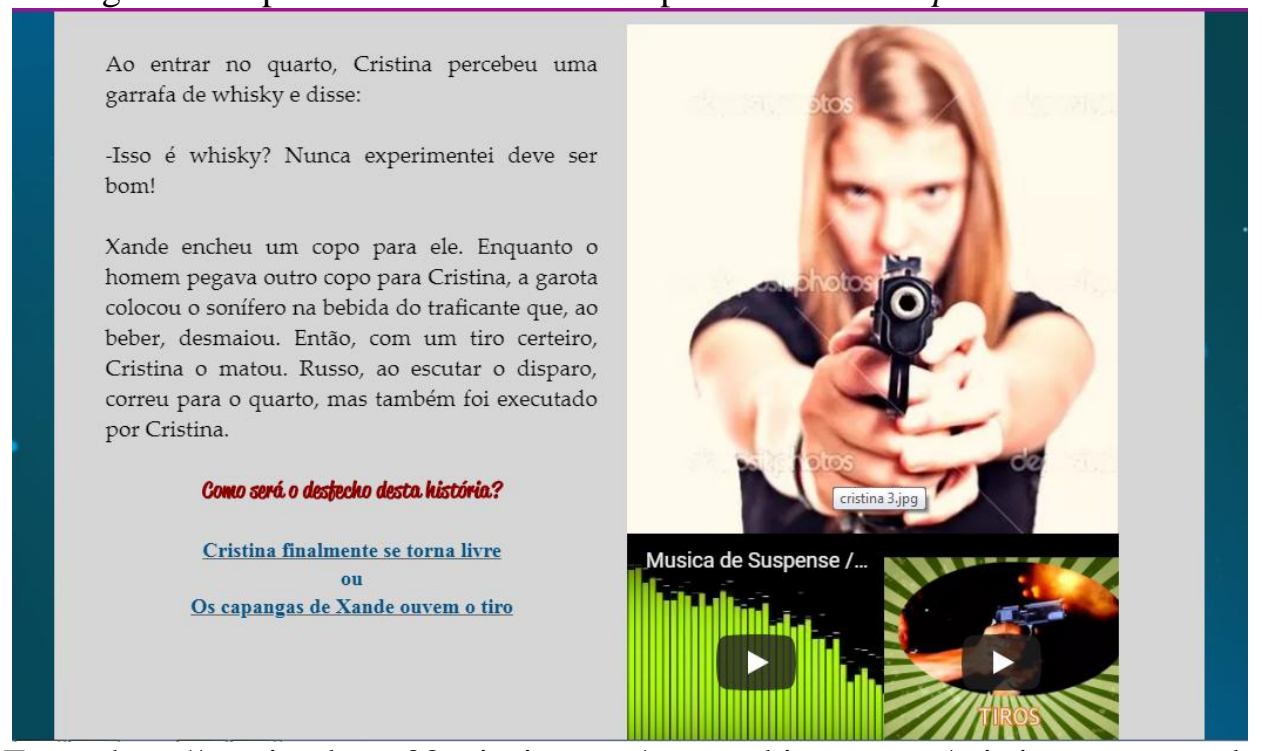

Fonte: http://garciaroberta38.wixsite.com/contosehipercontos/cristina-mata-xande

Pode-se observar que nessa tela, a penúltima do hiperconto, é o momento do desfecho da história, do clímax. Assim, após o professor ler o trecho que antecede o final, mais dois links são apresentados para que o leitor escolha o final da história. Notase também que, na imagem ao lado do texto, abaixo da garota, há um fundo musical de suspense, que o leitor pode clicar e ouvir ao mesmo tempo em que lê o texto, um 
recurso pouco utilizado em uma produção impressa, principalmente no contexto do Ensino Fundamental séries finais.

$\mathrm{Na}$ hora de escolherem o final da história, a maior parte dos alunos optou pelo primeiro link, cuja captura de tela se encontra abaixo.

Figura 6: Captura de tela da quarta e última tela do hiperconto Um tiro para a liberdade

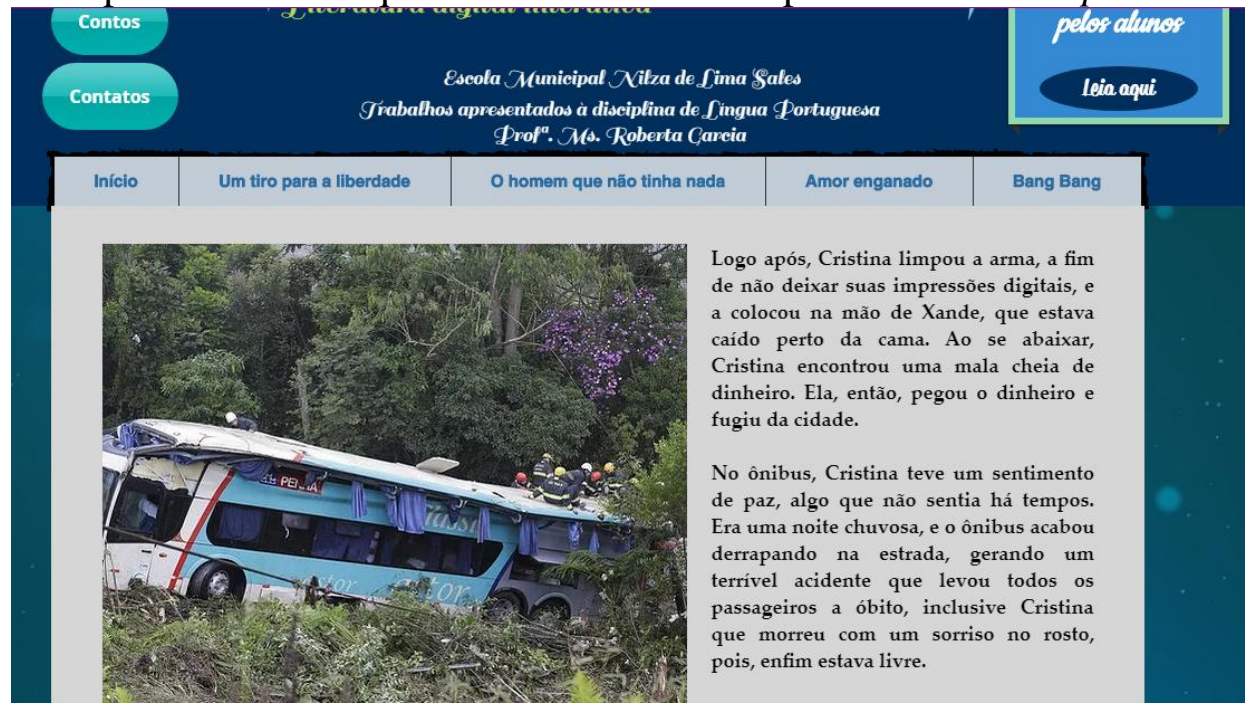

Fonte: http://garciaroberta38.wixsite.com/contosehipercontos/cristina-se-torna-livre

Nessa tela, temos o final do hiperconto, um final resultante das escolhas feitas pelo leitor durante o percurso da leitura. É fato que o autor criou todos os caminhos e possibilidades da história, mas ela só terminou do jeito que aqui se encontra por conta das escolhas feitas. Caso os links clicados tivessem sido outros, a história teria um final bem diferente.

Durante a segunda aula, foi apresentado aos alunos um hiperconto mais elaborado, que possibilitava ao aluno participar como personagem da história. O hiperconto apresentado foi Um estudo em vermelho, de autoria de Marcelo Spalding.

Figura 7: Captura da primeira tela do hiperconto Um estudo em vermelho ${ }^{12}$

\footnotetext{
${ }^{12}$ Faz-se necessário destacar que "Um Estudo em Vermelho" é um romance policial escrito por Sir Arthur Conan Doyle, publicado originalmente pela revista Beeton's Christmas Annual em novembro de 1887. Disponível em: https://pt.wikipedia.org/wiki/Um_Estudo_em_Vermelho. Acesso em 29 de novembro de 2018.
} 


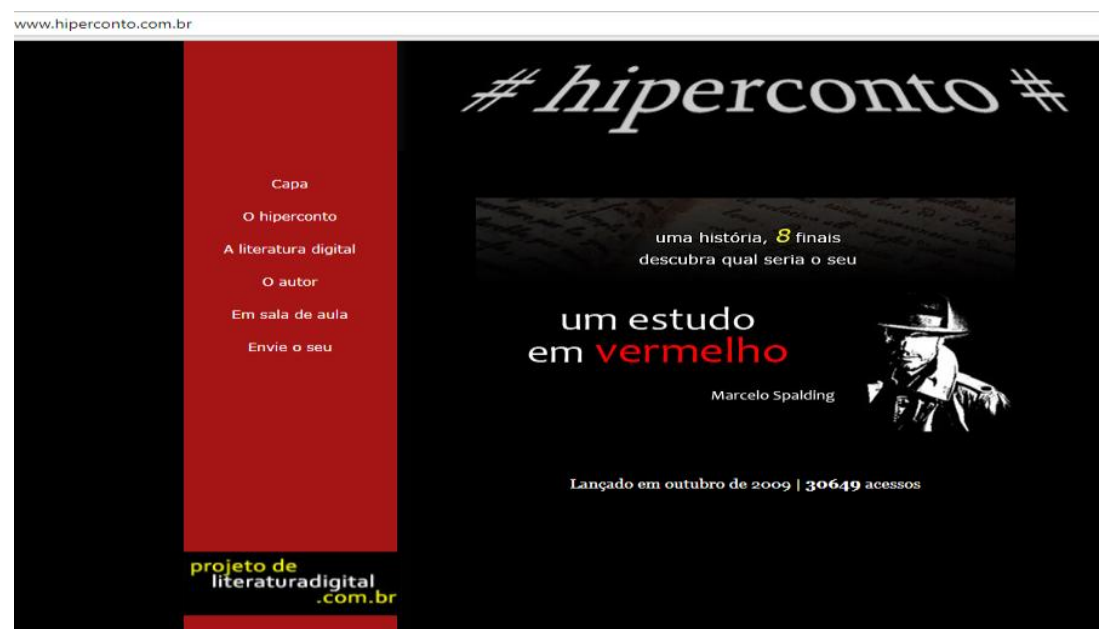

Fonte: http://www.hiperconto.com.br/

Nesse hiperconto, o leitor tem um papel ainda mais ativo do que no apresentado anteriormente, pois nesse ele se torna um personagem da história, tendo o seu nome presente durante toda a trama. Pode-se notar nessa tela o convite do autor para que o leitor escolha o seu próprio final dentre os 8 possíveis para a história. Nesse caso, é interessante que a leitura e a tessitura do hiperconto seja feita de forma individual, uma vez que o leitor precisa preencher dois espaços - um com o seu nome e outro com o seu e-mail, como se nota na imagem abaixo:

Figura 8: Captura da segunda tela do hiperconto Um estudo em vermelho www.hiperconto.com.br/estudoemvermelho/

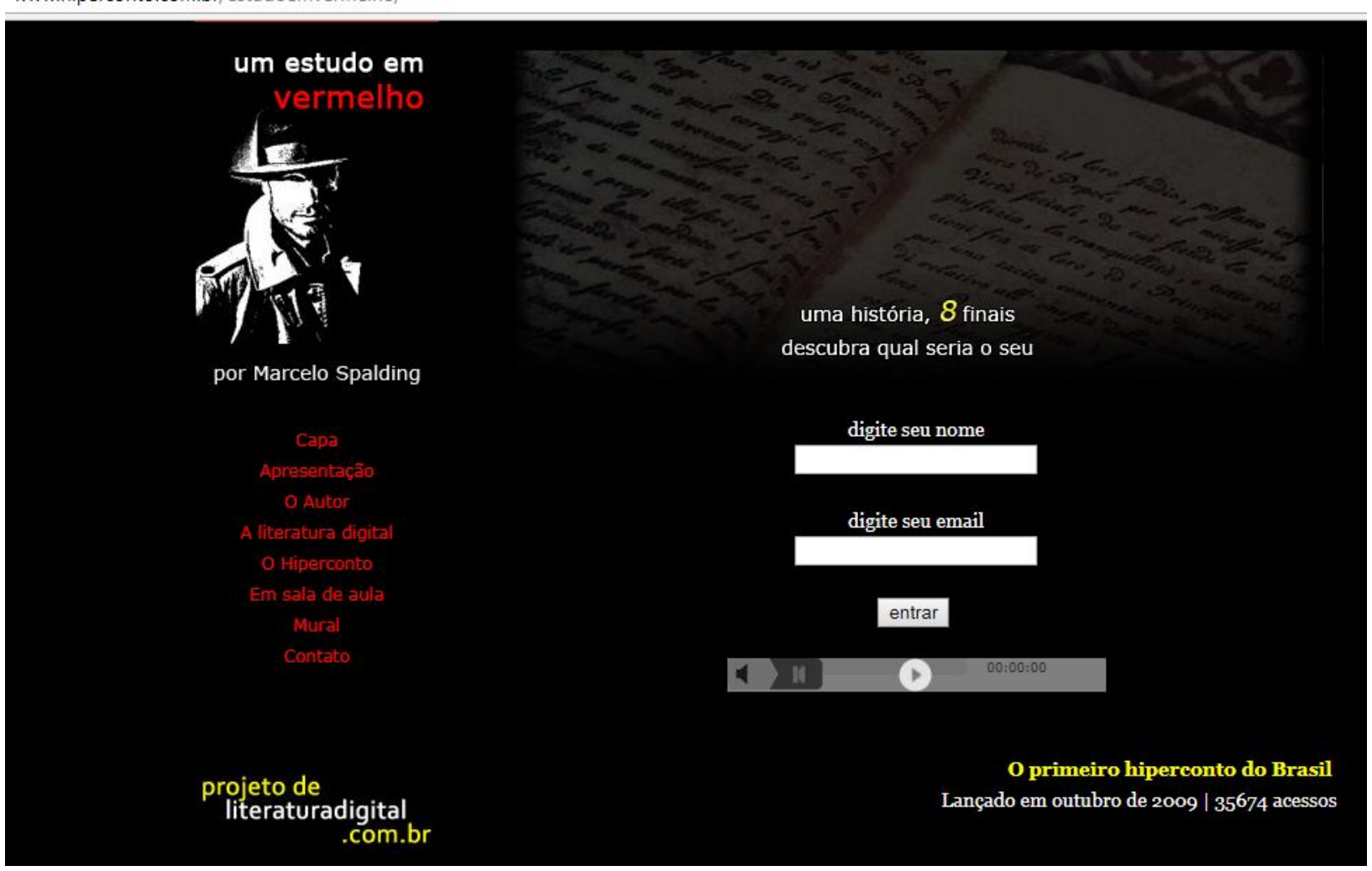

Fonte: http://www.hiperconto.com.br/estudoemvermelho/ 
Nesse momento, assim que foi explicado aos alunos como funcionava a leitura e participação no hiperconto Um estudo em vermelho, foi solicitado que um dos alunos preenchesse os dois espaços em branco na tela com seu nome e e-mail. O aluno M. se ofereceu para tal. Assim que ele preencheu os espaços e clicou em entrar, logo abaixo do $e$-mail, surgiu a tela seguinte.

Figura 9: Captura da terceira tela do hiperconto Um estudo em vermelho

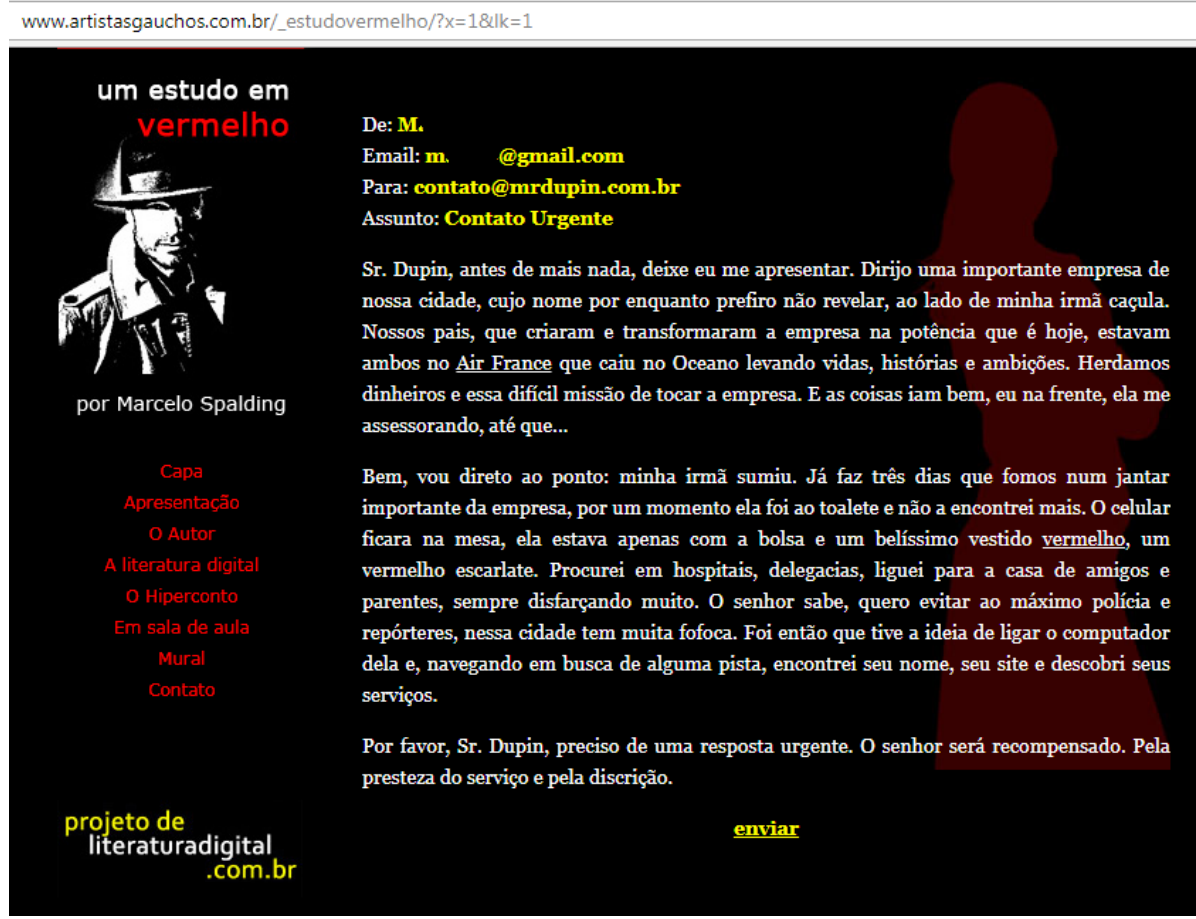

Fonte: http://www.artistasgauchos.com.br/_estudovermelho/?x=1\&lk=1

Como se pode notar na tela acima, o aluno M. aparece enviando um e-mail para o detetive Dupin, solicitando seus serviços para encontrar sua irmã desaparecida. Ao clicar em enviar, no final da tela, surge a próxima:

Figura10: Captura da quarta tela do hiperconto Um estudo em vermelho

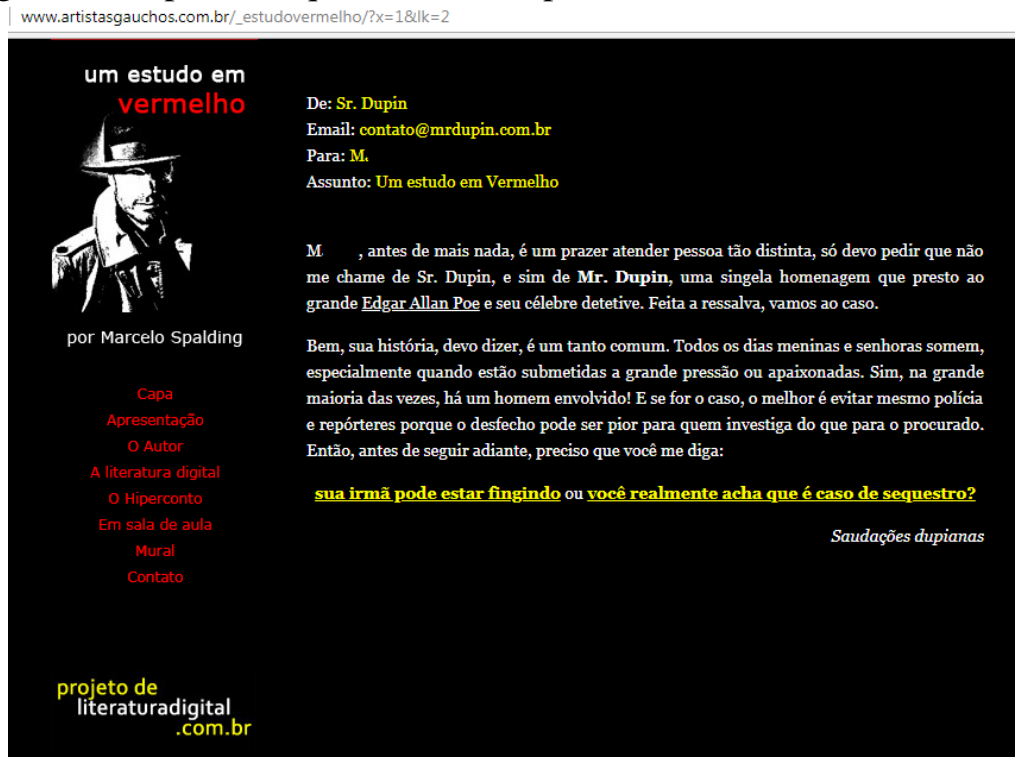


Fonte: http://www.artistasgauchos.com.br/_estudovermelho/?x=1\&lk=2

Nessa tela, o detetive Dupin responde ao e-mail de M., mostrando-se atencioso ao caso. Em seguida, faz dois questionamentos a M., através dos dois links em amarelo. A partir desse momento, a história será construída a partir das escolhas de M. ${ }^{13}$. Assim, depois de uma longa troca de mensagens entre M. e o detetive, a história tem o seguinte desfecho:

Figura 11: Captura da última tela do hiperconto Um estudo em vermelho

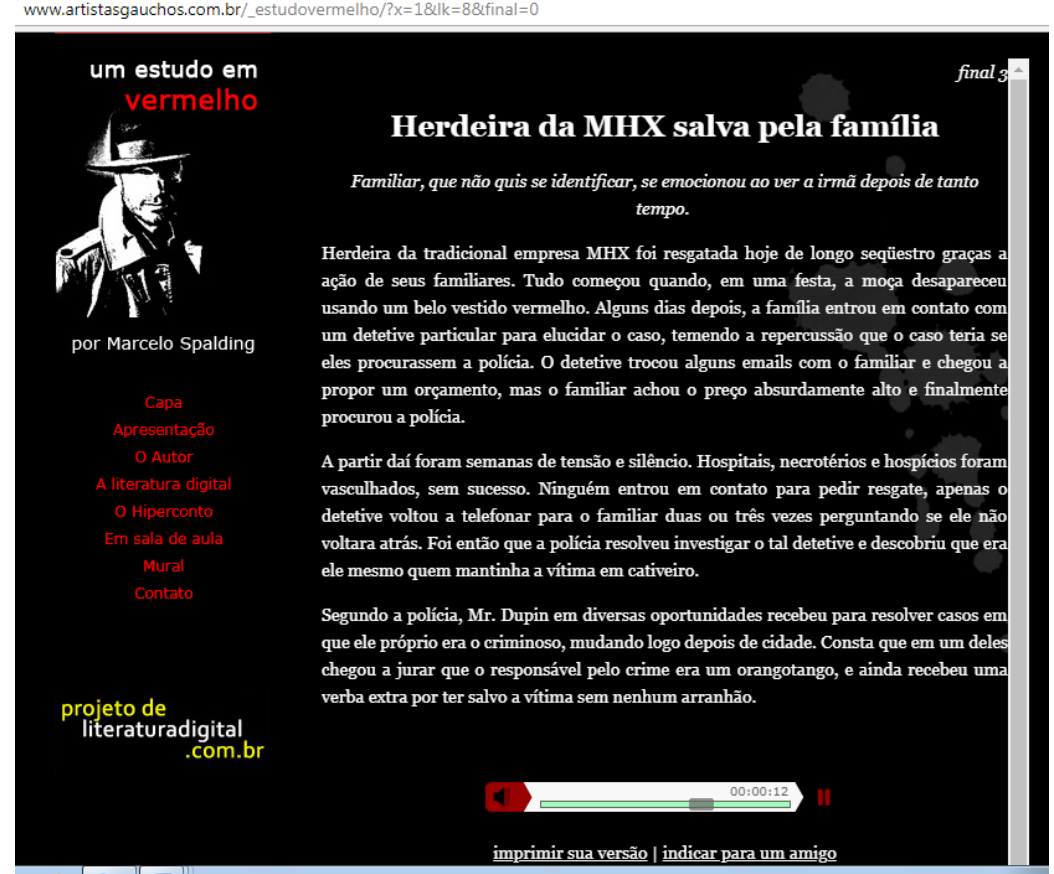

Fonte: http://www.artistasgauchos.com.br/_estudovermelho/?x=1\&lk=8\&final=0

Após essa aula, foi sugerido que os alunos, individualmente e em casa, explorassem os hipercontos Um tiro para a liberdade e Um estudo em vermelho, além dos outros hipercontos disponíveis nos dois sites. A ideia era que cada aluno pudesse fazer sua própria escolha, o que daria uma significação maior para a prática de leitura. Eles fizeram, e na aula posterior puderam falar com detalhes a respeito da experiência. Foi feito um círculo na sala de aula e cada aluno contou sobre os hipercontos lidos e como foi sua experiência de leitura. Foi um momento muito proveitoso, no qual se percebeu o efeito dessa prática de leitura ${ }^{14}$.

\subsection{Análise dos Dados}

\footnotetext{
${ }^{13}$ Devido ao fato de ser uma história com muitos links, não deu para colocar todas as capturas de tela, mas, através dessas primeiras e da última, dá para compreender perfeitamente como a história é construída a partir das escolhas do leitor.

${ }^{14}$ Vale frisar que essa prática não se esgotou nessa aula. Em aulas posteriores, os alunos exploraram outros sites de hipercontos indicados pelo professor. Além disso, eles foram organizados em trios para a produção de hipercontos. Essa produção encontra-se em andamento.
} 
A decisão de usar o hiperconto como forma de ampliar as possibilidades de leitura dos alunos do $9^{\circ}$ ano da turma alvo desta pesquisa e contribuir com a formação desses sujeitos mostrou-se acertada. Aproveitar o gosto dos discentes pelas novas tecnologias, em especial o celular, foi uma aposta certa, pois ficou nítido o quanto os alunos passaram a ler mais o texto literário, tendo em vista que o hiperconto, por ser uma nova versão do conto tradicional para a era digital, é um gênero literário. Isso ficou claro nas discussões em sala de aula, nas quais muitos alunos revelaram que, ao ler os hipercontos, às vezes não se contentavam com o final da história e acabavam reiniciando a leitura e escolhendo novos caminhos, na tentativa de encontrar um final mais condizentes com as suas próprias expectativas. Ao fazer isso, automaticamente eles estavam ampliando seus hábitos de leitura e exercitando o processo de construção da tessitura textual. Alguns alunos também revelaram que gostaram tanto da dinâmica dos hipercontos que leram todos os hipercontos dos sites indicados na sala, o que ratifica a ideia adotada no início desse trabalho, a de que fazer uso da tecnologia (algo que os alunos gostam) e adotar a literatura digital por meio do hiperconto é uma forma de trabalhar a leitura que traz resultados positivos, como defende Spalding (2012).

Frente ao exposto, esses resultados, apesar de parciais, demonstraram o quanto a literatura digital, neste caso representada pelos hipercontos, pode estimular os alunos, em um primeiro momento, a lerem cada vez mais a partir do suporte digital. Além disso, é fundamental ressaltar que, conforme os próprios alunos sinalizaram, o maior atrativo do hiperconto são os links, devido ao fato de possibilitarem aos leitores serem coprodutores dos textos ao fazerem suas escolhas, algo não muito comum no contexto literário, principalmente no referente à literatura impressa.

\section{Considerações Finais}

Apresentamos nesse trabalho alguns resultados iniciais obtidos com uma prática de leitura de hipercontos, oriunda do recorte de um Projeto de Qualificação de Mestrado em Letras, cuja preocupação esteve voltada para a ampliação do hábito de leitura e para a formação do leitor contemporâneo.

Vimos que, no momento atual, notadamente marcado pelo uso das Novas Tecnologias da Informação e Comunicação, uma parcela significativa dos alunos do contexto analisado tem deixado o livro impresso de lado, optando por fazer suas leituras, em grande parte, na tela, o que acaba sendo um desafio para os docentes que precisam encontrar meios eficazes para estimular os alunos no tocante à leitura do texto literário.

A literatura digital foi o caminho encontrado nesse trabalho que, através do gênero hiperconto, pôde trabalhar a leitura com os alunos, fazendo-os sentirem mais interesse por ler, devido ao que, para eles, foi uma novidade em literatura - a possibilidade de fazerem escolhas e participar da construção do texto, algo que eles provavelmente nunca haviam experimentado.

Um ponto bastante enfatizado nesse trabalho foi o descrédito que a literatura digital sofre por parte de alguns defensores da literatura impressa, como apontaram alguns autores, no entanto, buscou-se evidenciar que a literatura digital não está para 
competir com a impressa, pelo contrário, está para somar a essa, afinal, não há duas literaturas - há a literatura geral, sendo a literatura digital, portanto, apenas uma vertente daquela. Dessa forma, o que se almeja com a literatura digital é aproveitar o gosto dos discentes pela tecnologia e usar isso em favor de um leitor cada vez mais assíduo, seja no suporte impresso, seja no digital.

\section{Referências}

ABREU, Márcia. Cultura letrada: literatura e leitura. São Paulo: UNESP, 2006.

ARAÚJO, Júlio César; SOARES, Carla Poennia Gadelha. 2009. Afetividade, hipermodalidade e hipertextualidade nas interações no orkut. In: III Encontro Nacional sobre Hipertexto. Belo Horizonte. Disponível em http://nehte.com.br/hipertexto2009/anais/a/afetividade_hipertexto.pdf

BORDINI, Maria da Glória; AGUIAR, Vera Teixeira de. Literatura: a formação do leitor: alternativas metodológicas. Porto Alegre: Mercado Aberto, 1989.

BRAGA, Denise Bértoli; RICARTE, Ivan Luiz Marques. Letramento e tecnologia. Campinas: CEFIEL/IEL/Unicamp, 2005.

BRASIL. Brasil no PISA 2015: análises e reflexões sobre o desempenho dos estudantes brasileiros / OCDE-Organização para a Cooperação e Desenvolvimento Econômico. São Paulo: Fundação Santillana, 2016.

CÀNDIDO, Antônio. “O Direito à Literatura". In: Vários Escritos. São Paulo: Duas Cidades, 1995.

CANI, Josiane Brunetti. A Leitura Multimodal no Hiperconto Digital Um Estudo em Vermelho. In: Odisseia, Natal, v. 2, n. 1p. 113-132, 2017.

CHARTIER, Roger. Os desafios da escrita. São Paulo: UNESP, 2002.

COUTINHO, Gustavo Leuzinger. A Era dos Smartphones: Um estudo Exploratório sobre o uso dos Smartphones no Brasil. Brasília, 2014. 67 f. Monografia (Bacharelado em Publicidade e Propaganda), Universidade de Brasília.

DUARTE, Elaine Cristina Carvalho. Literatura em meio digital: um olhar sobre os novos perfis literários. In: XII Congresso Internacional da ABRALIC. Centro, Centros - Ética, Estética. Curitiba, UFPR, 2011. Disponível em: http://www.abralic.org.br/eventos/cong2011/AnaisOnline/resumos/TC0258-1.pdf, acesso em 25 de junho de 2018.

GOMES, L.F. Ainda o hipertexto: uma breve revisão. In: GOMES, L.F. Hipertexto no cotidiano escolar. São Paulo: Cortez, 2011.

HAYLES, N. Katherine. Literatura eletrônica: novos horizontes para o literário. São Paulo: Universidade de Passo Fundo, 2009. 
LEMKE, Jay L. Travels in Hypermodality. (2002). Disponível em http://journals.sagepub.com/doi/10.1177/147035720200100303

ROJO, Roxane Helena; MOURA, Eduardo. Multiletramentos na escola. São Paulo: Parábola Editorial, 2012.

SANTAELLA, Lúcia. Navegar no ciberespaço: o perfil cognitivo do leitor imersivo. São Paulo: Paulus, 2004.

SANTAELLA, Lúcia. Comunicação Ubíqua: representação na cultura e na educação. São Paulo: Paulus, 2013.

SANTOS, Áurea Maria Brandão; GROSS, Letícia Granado; SPALDING, Marcelo. Conexões entre letramento digital e literatura digital. In: Linguagem em Foco. Revista do Programa de Pós-Graduação em Linguística Aplicada da UECE. Ceará: v. 9, n. 1, p. 117-129, 2017.

SANTOS, Gerson Tenório dos. O leitor-modelo de Umberto Eco e o debate sobre os limites da interpretação. In: Kalíope, São Paulo, n. 2, p. 94-111, 2007.

SPALDING, Marcelo. Literatura na tela do computador: a coletânea de Literatura Eletrônica de Katherine Hayles e algumas experiências no Brasil. In: Revista Traj. Mult. - Ed. Esp. XVI Fórum Internacional de Educação - vol. 3, p. 138-155, 2012.

Recebido em 31 de junho de 2018

Aceito em 22 de novembro de 2018 